\title{
Australian Writing and the Contemporary Are We There Yet?
}

\section{ANNEE LAWRENCE}

WESTERN SYDNEY UNIVERSITY

\begin{abstract}
Well, Australia has written off Asia for almost 200 years; written off the countries of Asia, with cultural traditions of thousands of years. Perhaps it is time to write Asia; to write within it and of it, rather than just about it. The word Asia is found, after all, in the word Australia. If Australia wants to refigure itself in its relationship to the countries of Asia, to become part of Asia, as it were, then Asia must also be part of Australia.
\end{abstract}

In the deepest sense, art today is the product of a distinctively contemporary mix of cultural, technological, social, and geopolitical forces. By absorbing imaginable futures, and by contemporizing various competing visions of the past, this mix of forces has 'thickened' the present, and created a state of permanent transition, of perpetual contemporaneity. 
From the mid 1980s I worked closely with immigrants and immigrant communities in south western Sydney where, over the decades, I heard stories that linked me by a thousand threads to other times and places. This opened up ways of being and seeing the world that caused me to want to read literature that reflected the murmur of languages in a Sydney train carriage, or my joking conversations with the Iraqi barista at Bankstown Station who was a Greens supporter. In short, I wanted to read books that reflected not the exotic but the everyday, that everyday, in all its contemporaneity and diversity. Not memoirs, but imaginative and daring works that bonded with present day life and cracked open my Australian understandings of multiplicitous ways of dealing with and being in the world.

In this article I bring together Georgio Agamben's definition of the contemporary and Terry Smith's theory of world currents in contemporary art to examine whether, as in the third current's contemporary concerns, there is a comparable emerging stream in contemporary Australian literature that is distinct, regional and localised, but which 'frequently tries to imagine the world as a differentiated yet inevitably connected whole' $^{3}$

Informed by Smith's definitive work, I argue that three recent Australian texts-Michelle de Kretser's novel Questions of Travel, Chi Vu's novella Anguli Ma: A Gothic Tale and Jennifer Mackenzie's long poem borobodur ${ }^{4}$-shed light on an aspect of Australian literature that is in transition: becoming, by definition, in, of and with the world as well as in, of, and with present time. ${ }^{5}$ And, situated within it.

I also draw on Adrian Snodgrass's application of the metaphor of travel, excursion and return-combined with 'Sino-Japanese notions of the Way'-to consider the three texts in relation to the vectors that crisscross between them; and the ways they illuminate questions about Australian literature's 'imagined futures in the world', particularly in relation to the geographical region it inhabits. ${ }^{6}$

-DEFINING THE CONTEMPORARY

In an essay titled 'What Is the Contemporary?', Giorgio Agamben argues that 'the poet - the contemporary - ... firmly holds his gaze on his own time so as to perceive not its light, but rather its darkness'. ${ }^{7}$ It is this darkness that both concerns and 'never ceases to engage' her or him. ${ }^{8}$ It takes place in, and works within, chronological time and is something that 'urges, presses and transforms it'. ${ }^{9}$ 
For Agamben, 'the entry point to the present' equates to a kind of archaeology 'that returns to that part within the present that we are absolutely incapable of living'. It is the 'unlived element in everything that is lived', that is, the 'mass of what for some reason (its traumatic character, its excessive nearness) we have not yet managed to live. The attention to this "unlived" is the life of the contemporary. And to return to the contemporary means in this sense to return to a present where we have never been'.10

This sense of the contemporary as responding to and being in the present, its shadows and concerns, while at the same time bringing into present day focus the texts of the past, also shapes Terry Smith's theory of contemporary art in Contemporary Art: World Currents. According to Smith, the forces of globalisation in the world are causing deep changes so that even the "very idea of what a "nation" is is changing' and changing 'too fast for us to imagine what forms it will take in the years to come'.11 In the deepest sense, he argues, 'art today is the product of a distinctively contemporary mix of cultural, technological, social, and geopolitical forces' and the fluid nature of these forces are reflected in contemporary art's three world currents. ${ }^{12}$

Smith categorises the three currents as: Contemporary art (styles/practices); The postcolonial turn (ideologies/issues); The arts of contemporaneity (concerns/strategies). The first current, Contemporary art (styles/practices), is the art historical period style or art movement labelled 'late modern'.13 It is readily recognised by the brand name 'Contemporary Art' and represents 'the most celebrated, and controversial, forms of art' in contemporary art museums today. ${ }^{14}$ The second current, The postcolonial turn (ideologies/issues), originated within the many countries that have undergone decolonisation and its postcolonial aftereffects since the mid twentieth century. ${ }^{15}$ As well as its unprecedented diversity, Smith argues, this art making is, for the most part, 'content-driven', 'aware of the influence of ideologies, and concerned above all with issues of nationality, identity, and rights'. 16

Smith's third current, The arts of contemporaneity (concerns/strategies), is even more diverse and global and is 'markedly different' from art found in galleries and museums today. ${ }^{17}$ It is this current that draws attention to what he regards as a new paradigm and a potential break with Modernism, a shift towards new entanglement 
and interconnection at global and regional level. Lit by freshness, surprise, affect and diversity in its production, dissemination and range of materials, and also in the 'scope, specificity, and unpredictability of the questions' it raises, its creators-who are from all over the world-are more aware, and more quickly aware, of what their contemporaries are doing; and they 'seem much more interested in and open to it, than ever before'. ${ }^{18}$

By asking questions that drive below accepted narratives, Smith argues, these artists are interrogating the possible beneficial and detrimental effects of technological change on human and non-human alike, and challenging beliefs about human progress that accept the inevitability of continuous exploitation of the earth's resources. They are defining art's imaginable futures, and the way they are achieving this is through a:

search for a sense of locality within situations of constant disruption, dispersal, and displacement, their resistant awareness to the pervasive power of mass and official media, their acute sensitivity as to how these pressures affect everyone's sense of selfhood, and, finally, their interest in acting in ways that will improve the situation. ${ }^{19}$

The concerns of these younger artists are with the living conditions of the present as well as the questions arising from it 'as to the shapes of time, place, media and mood in the world today'.20 Identity and self-making are a central concern:

It leads them to ask: What is it to live, to exist, to be in contemporary conditions? The descriptive question 'How do we live now?', ... quickly becomes an ethical one: 'How might we live better?' ... [and they seek out] the multiplicity of ways of being in time ... and the variety of temporalities experienced by each of us every day (not least in our use of these new technologies). ${ }^{21}$

One example is video artist Fiona Tan, who traces the diaspora of her family through Indonesia, Hong Kong, Australia and Europe. ${ }^{22}$

This third current of arts practitioners is caught up in and/or witnessing unprecedented shifts in global power, the mass movement of people on an unprecedented scale-voluntary and involuntary, and rapidly developing real time communication technologies that bring into play multiple perspectives, allegiances, communities and ways of relating and engaging-within, between and beyond the 
national. Not only is the resultant explosion in diversity of art practice taking place far from the old Euro-American 'major centres', Smith argues, it also holds a place for the ephemeral, unrecorded and collaboratively produced.

In this article, I propose there is a thread emerging in Australian literature that is comparable to Smith's third current in contemporary art. It has the same characteristics of asking what it means to be living in, of and with the world at the present time, and it is bringing Australian readers to a new proximity, or intimacy, with 'Asia'. The texts I discuss are different genres but all three deal with travel, excursion and return, and time's multiplicities. They speak of crossing borders and stepping into different terrains, and invite hermeneutical understanding on the part of the reader who brings her own prejudices and experiences to the text. The 'institutions of intimacy' being managed in these texts relate to emotions, migratory experiences, alienation and marginalisation, place, spiritual practice and belief, family relationships, friendship, art practice, communities, workplaces and life journeys.

\section{-THe Australian IMAgINARY WITHIN 'Asia'}

Individually and collectively, the chosen texts mark a clear shift away from an aspect of the Australian literary imaginary that limits, exoticises or demonises, where it has been attempted at all, in its 'imaginative engagement with the Asia-Pacific region'.23 Nicholas Jose quotes Robin Gerster for whom the Australian imaginary in relation to the region has often been characterised by 'a peculiar combination of suspicious insularity and neo-colonial assertiveness and self centredness ... [both in] the way Australia sees its region and itself in relation to it'. ${ }^{24}$ Jose and Gerster both suggest a future Australian literature that is characterised by greater engagement with literatures from the Asia Pacific regions as well as a willingness to engage readers in the strange and unfamiliar.

Collectively, the three texts reflect a diversity in the Australian imaginary that, as Alison Ravenscroft argues in relation to Australian Indigenous authored writing, 'aims to show the impossibility of bringing all into representation, into language'.25 Such writing, she argues, 'endeavours to make a space for the enigmatic, not to reveal its content or size, not to give it measure, but to give it space where it can remain what it is-unknowable, unspeakable, invisible'. That is: 
writing that points to the relation between the known and the unknown, and which asks: how is the unarticulated and inarticulable productive, how does it bring some things into hearing and into view? And, can we read for what is not articulated or shown?26

Australian Indigenous authored writing is an example of such writing because it calls for a reading practice that "cannot any longer to be only "making sense"; a reading practice that finds where we can no longer read, where the text is silentfor whites at least-and where we in turn must observe our own silence'. Such a reading practice 'does not stitch up the gap in meaning, but lets the enigmatic and aporiatic'.27

While Ravenscroft wants to argue that this is where interpretation and the imaginative act fail', it could be argued that such a reading corresponds to a form of hermeneutical interpretation and understanding articulated by Hans-Georg Gadamer, in which the interpreter engages in a dialectic, a dialogue, with the text. ${ }^{28}$ He or she approaches the text with an open mind and a willingness to hear what the text has to say; that is, engages in a true conversation with it while accepting the truth it contains might differ 'from what I think to be true and is for that reason something that could change the way I see things'. ${ }^{29}$

In such a reading, where a text belongs to 'another life-world, removed in space and time', the interpreter (reader) 'relates it to his or her own familiar conceptual framework, while at the same time respecting and preserving its otherness and not simply appropriating it for his or her own purposes. Gadamer refers to this as a "fusion of horizons"'.30

The fusion of horizons, which takes place in all instances of interpretation and true understanding, does not imply moving into the position of the other, or applying our own criteria to them. On the contrary, what engages our interest is the unfamiliar, strange or unintelligible because this is where the hermeneutical task comes into play.

The unknown questions us ... We enter the unknown for what lies there to be discovered. In dialogue we wander in unexplored territory not with the intent of annexation, but of returning home to our own familiar horizons and seeing them in a new way because of what we have seen elsewhere. ${ }^{31}$ 
For Gadamer, true listening is not self-related, nor does it involve speaking for the other, or 'disallowing any appreciation of the differences that make another culture unique'. ${ }^{2}$ It is rather a reciprocal give and take that involves a genuine openness.

Without such openness to one another there is no genuine human bond.

Belonging together always also means being able to listen to one another.

When two people understand each other, this does not mean that one person 'understands' the other ... Openness to the other, then, involves recognizing that $\mathrm{I}$, myself, must accept some things that are against me, even though no one else forces me to do so.33

This suggests that a truly open reading of a text is one that does not deny it has anything new to offer, or that it can challenge our own beliefs and attitudes. Such an exchange is distinct from Orientalism for, as Edward W. Said argues in his preface to the 2003 edition of Orientalism: 'There is ... a profound difference between the will to understand for purposes of co-existence and humanist enlargement of horizons, and the will to dominate for the purposes of control and external dominion.' According to Said, the main characteristics of the former are sympathy, generosity and even hospitality where the mission is to 'apprehend, criticize, influence and judge'. And this is done, he says, by concentrating 'on the slow working together of cultures that overlap, borrow from each other, and live together in far more interesting ways than any abridged or inauthentic mode of understanding can allow'. 34

\section{-De Kretser, Chi Vu, Mackenzie}

The three texts deal with travel, excursion and return, and time's multiplicities. They invite the reader to enter into an absorbing question and answer conversation with the text that allows for an Other that is not entirely knowable within the reader's terms. It is their strangeness that brings into focus and bends the limits of our own horizons, and adds to our understanding of multiplicitous ways of being and seeing that exist within communities, and in relation to and connection with the geographical region Australia inhabits.

The novel Questions of Travel by Michelle de Kretser primarily follows the lives of two characters-Laura Fraser and Ravi Mendis-from the 1960s until 2004. Laura grows up in Sydney, Ravi in a village on the west coast of Sri Lanka. Over the 
decades, their life stories, and those of the people around them, are told through chronologically spliced scenes and episodes of childhood and adolescence, education and careers, travel, marriage (Ravi) and affairs (Laura).

As the new millennium looms, the world is on the move, in reality and virtually, and the novel is populated with characters who make voluntary and involuntary journeys, suffer trauma and displacement, or are linked in some way with those who have. Technology is rapidly transforming lives, global communication and the nature of work; and while computers, the internet, email, mobile phones and digital cameras appear exotic on first encounter, they quickly become commonplace in the characters' lives:

The web had grown from usefulness into beauty. It was as complex and various as a world ... a city of strangers and connections: people with different needs were drawn to it from far and wide. It thrilled with potential, magic, risk. Ravi's mouse clicked and clicked as if keeping timebut that was an illusion. Time spent online disappeared with the smooth efficiency of Ctrl-A + Delete. ${ }^{35}$

De Kretser dwells on the everyday and the novel's chronological form is an insistent reminder of time passing. Its loops, backtracks and fast forwards press down on Laura and Ravi and propel them through technological, social and political change. They go to work, socialise with friends and family, get to know neighbours, grow older, deal with pain, grief and loss. In layer on layer of the various subplots and backstories, people move towards and away from one another, towards and away from catastrophe. Like it or not, their lives are being shaped by movement, migration, and global and intercultural encounters.

The second text, Chi Vu's novella Anguli Ma: a Gothic Tale, is set in Melbourne in 1980, just three years after Đào, an older Vietnamese refugee, arrives in Australia. When Đào lets her garage to Anguli Ma, an abattoir worker, strange things happen and her relations with the man become increasingly menacing.

The novella opens with a description of 'The Monk' who is meditating by a very Australian river: 'He lowers his eyelids and returns to the breath ... The she-oaks and river red gums have within them light from the sun and nutrients from the soil.'36 Powerfully wrought, it is a darkly mysterious and haunting account of the challenge of making a new home in an alien place. Having survived the terrors of 
escape from Vietnam and a perilous boat journey, Đào faces new life threats and losses as grief, fear and violence infuse a surreal strangeness into the gothic world of the text.

The third text is Jennifer Mackenzie's imaginative and exquisite long poem borobodur which follows the life and travels of Gunavarman, the Kashmir-born priest architect of the Buddhist monument known as Borobudur, which was built in Central Java in the ninth century CE. ${ }^{37}$ In writing the poem Mackenzie drew on the Old Javanese Kakawin, or epics, which flourished from around 800-1500 CE, and which inspired her with: 'Their astounding beauty ... fine imagery, their exquisite attention to detail and delicate positioning of the voice within nature and within culture.'38 Other acknowledged influences are the poetry of the Japanese ninthcentury monk, scholar and poet, Kukai (774-835 CE), and the fourteenth-century Javanese classic, Negarakertagama, by the poet Mpu Prapanca.

-EXCURSION, RETURN AND THE FIVE WAY STATIONS

For Adrian Snodgrass, the metaphor of travel-excursion and return-serves as a 'master metaphor in philosophical hermeneutics, where it is seen as the movement at work in all processes of interpretation and understanding'. ${ }^{39}$ In his essay 'Random Thoughts on the Way', Snodgrass draws on Hans-Georg Gadamer's hermeneutical theory to suggest five variations of the metaphor, 'way stations or temporary stops' on the Sino Japanese notion of the 'Way', that apply to architectural education.

The five Way stations are bildung (architecture as a model for), the aimless wanderer (design as, and allowing for, the 'spontaneous appearance of ideas'), history ('the study of architectural history as a way of understanding prejudice'), 'the encounter with alien traditions as the most provocative means of transforming prejudice', and 'metaphor as a means for this transformation'. ${ }^{40}$ This application of Gadamer's approach to hermeneutical theory to architectural design practice also dovetails with his pedagogic interest in the study of Asian architecture.41

In the following, I engage Snodgrass's theorisation of Gadamer in order to illuminate a reading of the three texts in the context of Smith's description of the third current in contemporary art. 
The First Way Station-Bildung

The First Way Station denotes education in the sense of 'properly developing one's natural talents and capacities', ${ }^{42}$ and Snodgrass argues that in order to achieve this, one must leave home, that is, leave 'the locus of what one already understands and is at home with', and go to a 'new place that is strange and unfamiliar. As one comes to understand this other place, as it becomes familiar, it comes to be a new home'. ${ }^{43}$ In the process of acquiring 'this new homeliness', however, one is changed so that when one returns to the starting point, it is changed also. 'You see it in a new way, and understand it differently.' 44

In metaphorical terms, this describes the act of entering the alien and unfamiliar 'world' of a text we have not encountered before. That which seems strange, alien, foreign is so because we do not yet 'recognise ourselves in it ... [or] realise it as a possibility we already possess' ${ }^{45}$ It is a circular movement where 'every step of the way, right back to the home whence one started, is a movement into and through the strange and otherwise. Having returned, enriched, the intrepid traveller starts out again ... thus inscribing circles within circles' ${ }^{46}$

In all three texts, the characters make or have made journeys and the reader is invited to accompany them into the alien and unfamiliar, and make their own discoveries. In borobudur, fourteen-year-old Gunavarman travels from Kashmir to Central Java to become a companion to the young prince Balaputra in the Sailendra court of the regent Saratunga. At the age of twenty he joins the household of his first stone-carving master, and in $780 \mathrm{CE}$ he is dispatched on a twenty-year pilgrimage to India to prepare himself for the task of realising Saratunga's vision for building 'a mighty stupa'.

Go to Nalanda, stay at least ten years

Go to Sanchi and follow the carving of the great monks

Go to Ellora thrive among the artisans of the Mahayana

Come back with your hands trembling with wonder

and expertise. 47

Gunavarman's journeys are of cosmopolitan discovery and learning in preparation for the design and construction of Borobudur. They encircle the poem, taking him by sea and land from Java to China and India, and back to Java. 
In Anguli Ma: A Gothic Tale, it is August 1980 and a strange time in Australia because a baby has been killed by its parents or taken by a dingo in the Northern Territory. Đào and her three tenants, who have all fled from Vietnam by boat three years earlier, are reshaping their ruptured lives in Melbourne. Đào's son, Trung, and granddaughter, Tuyê't, live elsewhere in the city; and Đào's tenants are Bác, who left Vietnam with her son who died on the journey, and Sinh who travelled alone as a sixteen-year-old and now works as a cleaner in a motel. For six months, Sinh and Bác have been sharing a room at the back of Đào's house, and when Anguli Ma comes to see the room that has been let to them, Đào lets him rent the garage instead.

The novella opens with a brief scene with a meditating Monk, and scenes of him and his encounters with 'The Brown Man' are interspersed with the unfolding and, eventually, menacing events at Đào's house. Brief scraps of scenes from each character's point of view drive the narrative forward in the present. Each is dealing with their lives in a new country as well as their different ways of managing feelings of shame, grief, loss and loneliness. Their sense of helplessness is mixed with forlorn hopelessness or bitter disappointment, particularly for the older women and the man, Anguli Ma. For Đào, collecting and hoarding become an obsession, almost an obligation.

In Đào's house, a whole room is stuffed with found stuff and it is here that she hides her money and other valuables: 'at the bottom of a box of tissues; inside a ceramic vase bought at the Trash \& Treasures; in amongst the clean rags from the factory. Đào carefully rotated her hiding places, and was confident of her ability to recall the ever-changing sequence with the changing days and weeks. The boxes were filled with scraps of fabric which has been precision-cut, fifty layers at a time into shoulder panels, collars, torsos, scooped pockets ready for over-locking into tracksuits... 48

It is from this room that the collected moneys of the hui group members, which Đào is trusted to administer, are stolen by Anguli Ma, causing Đào to become a target for intimidation and retribution. On top of this loss, Sinh also disappears and Đào is fearful that the two events are connected. In her frantic repeated searching among the stuff, she begins to retrieve items like the orange-pink embroidered top that had 
'the aroma of topical fruit' that are invested with poignant memories of another time and place: 'Things she did not bring with her to Australia.' 49

It was as though they had floated up to the surface from forgotten crevices deep below ... She looked for Sinh amongst the impossible objects. For any clue about Sinh's whereabouts...50

Đào has had a warm bond with Sinh, much warmer than the coolly distant, and often fractious, relationship with her son and granddaughter, and now, in her horror at the loss of Sinh in the present, she decides to burn all the stuff in the hope that if she returns what belongs in the past to the past, she might find her young tenant.

\section{The Second Way Station-The aimless wanderer}

The Second Way Station refers to the traveller whose mind and feet simply follow the path of 'training for living one's life'. It recognises that: 'One's craft or profession is a way, a way of gaining understanding of the Way. One goes out to, gives oneself over to one's work, and thereby grows in being. All who work are journeymen and women, who perform a "journey", that is, literally, "a day's work".'51

This equates to the reader who approaches the text with an open mind, willing and accepting of 'what reveals itself' or where she is led. But this does not mean she approaches the text with a mind that is a tabula rasa. The interpreter brings with her a set of beliefs, experiences, attitudes, cultural norms and practices which constitute what Gadamer calls her 'prejudices' or 'horizons'.52 In the fusion of horizons, which occurs in every event of real understanding, we do not leave behind our own behind, nor do we enter 'the alien horizon so as to incorporate or appropriate something contained there'. For Gadamer, the question is central in the hermeneutical situation and he draws on R.G. Collingwood to argue that a text can only be understood when 'we have understood the question to which it is the answer'.53

In Questions of Travel, as the title suggests, travel, tourism, geography, migration, asylum and escape, geopolitics, and the crossing of borders are key themes. People make journeys for different reasons: for Laura's aunt Hazel it was flight, for Ravi it was to find safety, for Laura the pursuit of vague hopes and dreams. With a travel book in hand, Laura sets out to see the world and finds herself alien, out of place, and always facing the question, What are you doing here?' 
While Sydney beckons, and the romance of travel fades to homesickness, she discovers the joyfulness of looking at 'everything' like a child, and 'marvelling at the wonders of the world'.54 In a year in Naples, a place of uncompromising difference and mystery to her, Laura becomes most alive and open-the travel books are set aside, she teaches English, practises Italian, and allows the city to reveal its secrets and its magic. Through selling her travel writing pieces, her profession as a travel writer takes off.

Snodgrass notes that the Chinese ideogram for Tao, the Way, contains both the noun and verb, so that it is 'at once "the Way" and "going on the Way", 'In Chinese, a thing ... does not merely stand as an object in space, but continues in time. Space and time merge in the thing ... the path and the person going on the path move forward together'. ${ }^{55}$ This suggests that as we travel (or read a text), 'it is not so much we who "see" or experience things ... but that they are revealed, or unfolded, before us'.56

This echoes the mindfulness of the Brown Man in Anguli Ma: A Gothic Tale when he obeys the Monk's admonition to observe the breath and:

his mind drops between the churning waves of anguish into something underneath, as though submerged momentarily in another world. Resting beneath his wondering, agitated mind is the clear and still truth. He has his first taste of not grasping at the future. 57

Are the Brown Man and Anguli Ma one and the same? Alongside the story of Đào and her tenants, there is the Brown Man's story of being drawn to listen to the Monk and obey his instructions to meditate. He finds himself changing, unable to kill a dog, beaten:

'What have you done? I can't kill even a wild animal anymore.'

The monk observes the dejected man before him, a man shaken by something arising from beneath the surface. He lowers his voice and urges the man to go further into his wretchedness, to lean into his fear. ${ }^{58}$

The Monk instructs him to kill one more time, "This time you should choose ... your most worthy victim ... someone much dearer to you, and much more dangerous to you'.59 The Monk's provocation forces the Brown Man to recognise that 'the 'most dangerous person to him is indeed himself'60 and so, after he has killed the young woman, Sinh, he goes to a cave to meditate and it is there that he is touched by the act of killing. 
His mind wanders to the icy fingers that touch his shoulder in the middle of the night. He can no longer tell whether this is a dream, a hallucination, or that he has been awakened by her; her body, so beautiful, except the bloody stumps where the fingers had been. The man feels the weight of it, the sacrificial garland, the flesh and nails of it. Ice fingers touching him in the night. ${ }^{61}$

After all the 'storms of anger and violence' have emptied out the Brown Man, he 'is ready to experience loss' and the pain in his body: 'increasingly it is not his pain experienced in his body: it is simply pain, or its twin, hope, and it arises and then departs'. In a final scene the Brown Man recognises the 'nature of Emptiness' and observes the 'dying down of his anger'.62

\section{The Third Way Station-History}

The Third Way Station is where travellers are 'always already further along the path than they are "in fact" ... [and] are, in a sense, always already at a destination, but the destination is never reached, because it changes at each step they take'.63 In the cycle of understanding, the hermeneutical circle:

our encounter with what lies ahead alters our understanding of what went before; and the altered understanding of what went before in turn alters our pre-understanding of what lies ahead. In projecting our understanding, we develop understanding. Our understanding grows by projection, by anticipating what's to come ... The past plays into the future. The way that has been traversed shines forward into present understanding, both conscious and tacit, and ahead into what is yet to come. 64

In Questions of Travel, past, present and future interact and intertwine. For example, at Ravi's workplace at the university in Sri Lanka in the 1990s, he and his colleague, Nimal Corea, take on the Math Department's sole dial-up computer and discover 'surfing the net'. 'Space had come undone, said Ravi. He spoke of flight and speed', but 'Five or six years later, when dial-up and Mosaic were dim monuments to digital prehistory, he would recall how slow it had really been'.65

The civil war is underway in Sri Lanka, the times are 'unnatural, out of joint', and ' $[\mathrm{w}] \mathrm{ar}$ and peace, anarchy and government were no longer discrete colours but 
had run together and changed hue'.66 Cruel acts are carried out with impunity and brutalising violence and deadly conflict form a chill backdrop to everyday lives, as when Ravi's cousins speak 'with satisfaction of a lane where each driveway contained a body with a dark circle in the forehead'. ${ }^{67}$

In her job with an NGO for the rights of women and children, Ravi's wife, Malini, resists such 'normalisation' and calls publicly on all sides to put an end to the terror and suffering. Although Malini's growing activism is not shared by Ravi, it is, she feels, bringing her a step closer to her schoolgirl self's 'capital-letter promise' to 'not live her life in vain'.

Following the murder of his wife and son, Ravi's life is turned upside down and he is helped to flee to Australia where he settles in Sydney. Here he finds a place to live and work, but the strangeness of the journey, in the shadow of overwhelming grief and loss that cannot be shared, is unsettling and poignant.

\section{The Fourth Way Station-Alien traditions}

The Fourth Way Station is where the value of what the traveller brings home is proportional to the difficulty of the terrain and the remoteness of the country in which she travelled and, in particular, the unfamiliarity and foreignness of the culture she encountered'.68 The purpose of the journey, therefore, is not to increase knowledge, 'but to keep alive an awareness that there are other types of ... understanding'.69

Questions of Travel stimulates questions about the everyday effects of globalisation. It asks the reader to consider: is everything including literature, and everyone, in a state of becoming-on the move, displaced, borderline, transitional, in flux? What is curiosity? Empathy? Compassion? What power do words such as 'race' still hold? What does it mean to offer refuge and hospitality? And, in what ways do small acts of kindness make cities (and countries) kinder places, and vice versa?

Feelings of loss and loneliness, acts of kindness or cruelty, and haunting memories, provide layers of affect that are stabbed to intensity by De Kretser's incisive humour and ironical juxtaposition. Characters' insights belatedly follow actions, as do flashes of remorse, relief, guilt or shame. Their actions raise questions about how individuals and societies choose to live (and work) with others, in communities and in the world. 
Some of the strongest (and more comedic) scenes in Questions of Travel are its exposè of the absurdities of the globalised workplace. At Ramsey Publishers, where Ravi and Laura work, De Kretser parodies the inconsequential emails, performance appraisals, motivational slogans, interoffice rivalry, indiscretions, restructures, redundancies, rumours and repetition. What seems exciting and glamorous when Ravi first starts to work there-the 'energy and confidence and postindustrial track lighting' that 'left nowhere to hide'-soon loses its gloss. ${ }^{70}$

Ravi's colleagues do not suspect the unspeakability of his suffering and their ignorance highlights what we choose to know about the people we meet, or how we might fail to bear meaningful witness to their ongoing suffering from the effects of trauma, violence and severe cruelty. For his young female colleague, Crystal Bowles, Ravi is just not cool, 'Have you noticed his jeans? Kmart!', while his boss, Tyler, ponders, 'He was a nice guy but not the right kind of person; could it be that he wasn't the right kind of refugee?'71

In borobudur, journeys are a metaphor for the creative process as well as being integral to it. In a review, Stephen Atkinson notes that journeys 'actual and metaphorical, geographical and spiritual, and the cultural exchanges they facilitate' are central to the poem and the poet.

For Mackenzie, wandering and poetry are in many regards the one thing, both conducted along similar trajectories and according to the same states of mind. With regard to the creative process of writing borobudur [Mackenzie] has said, 'texts, my own travels and experiences pointed in a certain direction and I followed'. 72

This is echoed in Gunavarman's years of study, his constant and restless movement, and pursuit of expertise, at the Buddhist University of Nalanda in India.73

I used my cell for storage in ten years at Nalanda

barely spent a night in it

wandering the streets

journeys to the interior

my wrists my palms my fingertips

in those days burned with passion

As time passes, his vision of the monument takes shape.

when I visited the stupa at Sanchi 
I could not see it as it was

but as at some other place

in the jungle south of Merapi ${ }^{74}$

Mackenzie's text wanders in time and space and is peopled with characters, some historical and some from another era altogether. Its opening portrait, 'Lamentation for My Beloved Student, the Rong'geng', paints his brother's consort and a student of Gunavarman:

She was raucous in the early days

my brother, Kanwa, was holding in his compound some

celebration for our father she was a gate-crasher but her

wit transformed indignation into merriment

Kanwa's dancers, whom he was training to move like puppet

butterflies

stepped aside to allow her garrulous cadences full scope ${ }^{75}$

The poem is filled with the scents, plants, forest vines, and scenes of everyday life, court life, and pageantry, its sections dated 4AD, 800 Ad, 689 AD, 780 AD.

The compound, like others in Java, is invisible from a distance,

surrounded as dwellings are by thick, sweet-smelling foliage,

tall palms and fruit trees this compound is particularly large,

empty fields used for market days and festivals others sown

to rice bent figures among the green like diaphanous flowers. ${ }^{76}$

In time Gunavarman's dream of the mighty stupa grows, igniting and exciting both ruler and architect. Biographical notes, demons, a boy summoned from afar, his stone carving apprenticeships with Monaguna and Kertayasha, the seasons, notes on the journey to Kertayasha, love lost, time passing, and finally the threat of war. There is a voyage to China in 780 AD to stay with the Sanskrit scholar, I Tsing, who presents him 'with sandals/dyed the blue of an iris/and cotton-filled coats doubling as pillows', and then despatches him overland to India in the company of two monks in search of sacred books. ${ }^{77}$

All the while, and throughout, Gunavarman is collecting scenes and images that will be carved into the design of the monument, and which are depicted in the photographs of details of the present day monument in the poem. Also inserted is a description of the ruler's 'tour of the realm' by Prapanca-poetic licence on the part 
of the poet as Prapanca lived some centuries later. In the end, peace is threatened, Prapanca is banished from the court, Balaputra slain, and the poem ends: 'I, Gunavarman/a dot/on/the/horizon.'

The poem is uplifting, magical, and rich in detail, much like the monument and its surrounds in the present day. For anyone familiar with Borobudur, or with Central Java, it resonates with truth and tropical atmosphere, a thread to an ancient empire and civilisation. And for others, it is a journey into the unfamiliar, the unknown, in another time and place. Mackenzie's recreation of the birth of the monument is rich with historical detail, character, feeling, myth and legend-an imaginative recreation of the birth of an idea that became the reality of a mighty monument that was 'lost' to the wider world for centuries in the jungle of Central Java.

\section{The Fifth Way Station-Metaphor}

The Fifth Way Station suggests that metaphor offers a translation of the present situation that goes beyond simply citing similarities.

Time slips and slides in all three texts. In Chi Vu's Anguli Ma: A Gothic Tale, events occur, and then there are rewinds. Time zones overlap and myth inserts itself-the Buddhist story of Angulimala is of a vicious killer who murdered his victims and kept a necklace of a finger from each one around his neck. When he meets the Buddha he has already killed 999 victims but finds he is unable 'to kill' the Buddha. Faced with the Buddha's compassion Angulimala renounces his life as a killer and becomes a disciple.

What can the interpretation of the myth in the novella tell us about the present? Snodgrass and Coyne argue that 'if a myth is to be understood today it must be interpreted in ways that relate to our present existential condition' ${ }^{78}$ In this reading, myth is metaphor that plays 'a social function in bringing to light meanings that provide a basis for ... a sense of social community'. ${ }^{79}$

After slaughtering, cooking and eating a dog, a rare delicacy, Anguli Ma and his friend sit in silence and forget for a moment the loss of their homeland before realising that 'their old life, and youth were both gone forever'. The next day when Đào's tenant, Bác, sees her cleaning up the blood from the butchered dog, she says, 'We think we left this behind when we escaped'; and Đào knows she is referring to 
'[w]andering hungry ghosts'. Bác says, 'We think we have a new beginning because we escaped the terror, and came to a new land. But we haven't left them behind, they came with us! Can't you see it?'80

In a final dream Đào dreams that she has found and put on the lei with Sinh's fingers dangling from it: 'She stepped back to look at her own monstrous visage in the mirror. Singh's nails twinkled at her décolletage. Đào's own fingers were like jewels amongst the stony, dessicated fingers; her living fingers and those of the dead intermingled.' In the dream, Đào pledges vengeance when the offender returns to her 'with his head shaven and wearing the simple garb of a beggar ... she will be old, but ready. She will not even hear the words of an enlightened being. She will make a wreath of his fingers ...'81

As Nicholas Jose points out, Chi Vu's Anguli Ma: A Gothic Tale transposes 'the Gothic into a horrifying imaginative narrative of the experience of Vietnamese refugees in suburban Melbourne as they deal with their demons in the years after arriving as "boat people"'. As well as playing out a 'most severe psychodrama', the 'trauma it narrates is stitched into domestic suburban ordinariness with dark, sharp brilliance, to produce "a jewel of terror"'. 82

In Smith's terms, the three texts perform original leaps of the imagination that cannot be simply grasped but which ask how we could live better, with greater curiosity, compassion, understanding, as well as with, of and in the present. They are contemporary, locally grounded, but also regionally and globally connected. There are common threads but their value lies in their diversity, freshness and ability to surprise. They invite questions about how literature can stir up prejudices (prior understandings), expand understanding of others and lay a basis for fresh understandings of the present.

Like the art making of Smith's third current contemporary artists, the texts conjure multiple ways of relating to the temporal and the a-temporal. They exemplify what he argues is a major shift in contemporary art-away from 'presumptions about art's universality to awareness that new kinds of art [are] coming from the world, connecting cultures all over the globe, thus creating, genuinely, an art of the world'. 83 
De Kretser, Chi $\mathrm{Vu}$ and Mackenzie imaginatively posit encounters beyond national borders and boundaries, across time and space, that individually and collectively suggest an emerging Australian literature we have not seen before. They show a plurality and interregional connectedness as well as a shift in gaze that embraces multilinguistic and cultural communities within, suggest hospitality and the welcome of strangers as the flipside of hostility and suspicion, and engender intercultural encounters. In the case of borobodur, the text has already been translated into Indonesian and is published in Indonesia by Lontar Press.

Despite fundamental differences in the disciplines of literature, visual art and architecture, this article recognises that there is much to be gained from bringing them into a conversation about the place of 'Asia' in the Australian imaginary. The three texts mark a shift in the Australian imaginary that lights up the possibility of imagining an entity of nation that is distinctively and, at the same time, regionally and globally connected, and deeply and differently 'entangled' with the world. And, while Michelle de Kretser and Chi Vu have Sri Lankan and Vietnamese backgrounds respectively, Jennifer Mackenzie is inspired by the rich cultural and literary traditions of Java and Japan.

Australia's geographical location (within 'Asia')—seen as a negative (being out of place) when, even into the twenty-first century, the nation defined itself as culturally and aspirationally linked to the arts of major Euro-American cultural centres (the 'West') - must now be re-evaluated. After two hundred years of white settlement and immigration, and of turning its back on the region in which it is located, these three texts contextualise greater connectedness and more complex encounters within Australian literature and the Australian imaginary in relation to the Asia Pacific region. They raise questions, make the familiar unfamiliar, and invite new ways of imaginatively engaging with and being in the region and the world.

Annee Lawrence completed a PhD at the Writing and Society Research Centre, University of Western Sydney. Her research included a novel set in Australia and Indonesia and a dissertation on aesthetics, ethics, alterity and form in the cross- 
cultural novel. She has recently published in Griffith Review and New Writing: The International Journal for the Practice and Theory of Creative Writing.

\footnotetext{
-NOTES

1 Brian Castro, 'Writing Asia', Australian Humanities Review, April 1996,

<http://www.australianhumanitiesreview.org/archive/Issue-April-1996/Castro.html>.

2 Terry Smith, Contemporary Art: World Currents, Laurence King Publishing, London, 2011, p. 316.

3 Ibid., p. 8.

4 Michelle De Kretser, Questions of Travel, Allen and Unwin, Sydney, 2012. Chi Vu, Anguli Ma: A Gothic

Tale, Giramondo, Sydney, 2012. Jennifer Mackenzie, borobodur, Transit Lounge Publishing, Melbourne, 2009.

5 Smith, p. 325. I am referencing here Smith's assertion that 'since the 1980 s contemporary art has shifted ... to awareness that new kinds of art were coming from the world, connecting cultures all over the globe, thus creating, genuinely, an art of the world. Perhaps, ten years hence, we will be able to look back at the present and say that, in the first decades of the twenty-first century, contemporary art began to be an art for the world.'

${ }^{6}$ Adrian Snodgrass, 'Random Thoughts on the Way: The Architecture of Excursion and Return', Architectural Theory Review, vol. 6, no. 1, 2001, pp. 1-15.

7 Giorgio Agamben, What is an Apparatus? And Other Essays, trans. David Kishik and Stefan Pedatella, Stanford University Press, Stanford, 2009, p. 44.

8 Ibid., p. 45.

9 Ibid., p. 47.

10 Ibid., pp. 51-2, emphasis added.

11 Smith, p. 258.

12 Ibid., p. 316.

13 Ibid., p. 11. Smith characterises 'art movements' as 'changes in the history of art and architecture akin to those that have become familiar since Realism, Impressionism, and the succeeding avantgardes'.

14 Ibid. Smith argues that the two strands of this current have run their course, with RetroSensationalism (Jeff Koons, Damien Hirst, Takashi Murakami) now appearing 'jaded' (despite continuing to resonate in China), and Remodernism's late and mid-career major practitioners such as Richard Serra, Gerhard Richter, Jeff Wall and Andreas Gursky still continuing to 'mine it for its remaining lode of inspiration' (p. 317).
} 
15 Ibid. This current includes artists working 'within centres of geopolitical power who are critical of their government's exercise' of it. He identifies its most outstanding exponents as including, for example, Ilya Kabakov, Tani Bruguera, Xu Bing, the Raqs Media Collective, John Mawurndjul, Yinka Shonibare, William Kentridge, Shirin Neshat, Steve McQueen and Isaac Julien.

16 Ibid., p. 322. One of this current's outcomes has been 'a poetic approach to politics' which, he warns, presents a challenge to its artists 'to resist the temptation of slipping into a new kind of distracted exoticism, one that would permit viewers gently guided tours through signs of the Other rather than obliging them to undergo genuine encounters with its intractable difference'.

17 Ibid., p. 8. According to Smith, not all art being produced today is contemporary as, for example, with artists who are exploring and refining older traditions as a 'deliberate response to the present'; at the same time, others choose to explore 'the more subtle nuances of the once shockingly new styles of the twentieth-century Modernist avant-gardes'.

18 Ibid., p. 325; p. 256 (emphasis added).

19 Ibid., p. 11.

20 Ibid., p. 11.

21 Ibid., p. 296.

22 Ibid., p. 322. Smith writes of Tan that her 'understanding of her own personality as dispersed back through time and across space, as shaped by broad historical forces and specific family memoriesalong with her ironic characterization of her artistic persona as that of "a professional foreigner" - is precisely what enables her to picture the multiplicities flowing through the present'.

23 Nicholas Jose, 'Everyday and Exotic: Australian Asian Writing', The Long View-Wheeler Centre:

Books, Writing, Ideas, 2011, p. 2, <http://wheelercentre.com/projects/the-long-view/book/everydayand-exotic-australian-asian-writing/>.

${ }^{24}$ Quoted in Jose, p. 2. See also Robin Gerster, 'Representations of Asia', in Peter Pierce (ed.), The Cambridge History of Australian Literature, Cambridge University Press, Cambridge, 2009.

${ }^{25}$ Alison Ravenscroft, The Postcolonial Eye: White Australian Desire and the Visual Field of Race, Ashgate Publishing, Surrey, 2012, p. 18.

26 Ibid.

27 Ibid., p. 20.

${ }^{28}$ Adrian Snodgrass, 'Asian Studies and the Fusion of Horizons', Asian Studies Review, vol. 15, no. 3, 1992, pp. 81-95. I am particularly indebted to this article for leading me to Hans-Georg Gadamer's hermeneutical philosophy, theorisation of three types of I-Thou encounters, and its potential for informing an ethical Australian and pedagogical engagement and encounter with Asia. For example, Snodgrass argues, 'Hermeneutics is concerned with the way in which we interpret and arrive at an understanding of a text, but its findings can be extrapolated to every event of interpretation and understanding, including the interpretation and understanding of Asian modes of thought or action' (p. 83). As well as Gadamer, Snodgrass acknowledges Kathleen Wright's commentary on the I-Thou 
relationship in her article 'Gadamer: The Speculative Structure of Language', in Brice R. Wachterhauser (ed.), Hermeneutics and Modern Philosophy, State University of New York Press, Albany, 1986, pp. 193218.

${ }^{29}$ Hans-Georg Gadamer, Truth and Method, 2nd rev. edn., trans. and revised Joel Weinsheimer and Donald G. Marshall, Continuum Publishing, New York, 2000. Quoted in Snodgrass and Coyne, p. 179. 30 Snodgrass, 'Asian Studies and the Fusion of Horizons', p. 86.

31 Ibid. p. 91.

32 Gadamer, p. 368, quoted in Snodgrass, 'Asian Studies and the Fusion of Horizons', p. 86.

33 Gadamer, p. 361.

${ }^{34}$ Edward W. Said, Orientalism, Routledge and Kegan Paul, London, 2003, pp. xiv, xxii.

35 De Kretser, pp. 285-6.

${ }^{36} \mathrm{Chi} \mathrm{Vu}, \mathrm{p} .1$.

37 The monument known as 'Borobodur' took seventy-five years to construct, was abandoned in the fourteenth century. Its existence only became known to the outside world in 1814.

38 Jennifer Mackenzie, 'Writing Borobodur', Sotto Magazine, October 2012,

<http://www.australianpoetry.org/2012/10/18/writing-borobudur/>.

${ }^{39}$ Snodgrass, 'Random Thoughts on the Way, p. 1.

40 Ibid.

${ }^{41}$ Snodgrass, 'Asian Studies and the Fusion of Horizons', pp. 92-3. Snodgrass argues, for example: Gadamer's insights indicate that the teaching of languages considered as objects and the teaching of facts-economic, political, historical, cultural or whatever-are not enough to give students the skills needed to understand Asia. To view the Thou [Asian phenomena] as an object, Gadamer claims, precludes or hinders understanding ... the study of artworks is of little avail in enhancing understanding if they are considered solely as objects of aesthetic, historical, exotic, decorative, or monetary interest. Artworks prompt understanding only when they are seen as truth-tellers which carry meanings to question us and reveal new aspects of the world and ourselves.

42 Hans-Georg Gadamer, quoted in Snodgrass 2001, p. 2.

43 Snodgrass, 'Random Thoughts on the Way', p. 2.

44 Ibid.

45 Ibid.

46 Ibid.

47 Mackenzie, pp. 27-8.

${ }^{48} \mathrm{Chi} \mathrm{Vu}$, p. 27.

49 Ibid., p. 89.

50 Ibid., p. 92.

51 Ibid, p. 4. 
52 Snodgrass, 'Asian Studies and the Fusion of Horizons', p. 86.

53 Ibid. Gadamer argues that this is like understanding works of art. A work of art can be understood only if we assume its adequacy as an expression of an artistic idea. Here too we have to discover the question which it answers, if we are to understand it as an answer' (p. 370).

54 de Kretser, pp. 71-2.

55 Snodgrass, 'Random Thoughts on the Way', p. 5.

56 Ibid.

$57 \mathrm{Chi} \mathrm{Vu,} \mathrm{p.} 25$.

58 Ibid, p. 58.

59 Ibid, p. 59.

60 Ibid, p. 70.

61 Ibid, p. 83.

62 Ibid., p. 96; p. 105.

${ }^{63}$ Snodgrass, 'Random Thoughts on the Way', p. 8.

64 Ibid.

65 de Kretser, p. 137.

${ }^{66}$ Intertextual references such as these to Hamlet, Act 1, Sc 5, lines 27-8 and 188 appear often in the novel. The Sri Lankan Civil War lasted from July 1983 until May 2009 and an estimated 80,000100,000 people were killed (UN estimate); de Kretser, p. 64.

67 Ibid., p. 63.

${ }^{68}$ Snodgrass, 'Random Thoughts on the Way', p. 10.

69 Ibid., p. 11.

70 de Kretser, p. 373.

71 Ibid., p. 470; p. 473

72 Stephen Atkinson, 'Review: Borobodur by Jennifer Mackenzie', Mascara Literary Review, 2007, $<$ http://mascarareview.com/stephen-atkinson-reviews-borobudur-by-jennifer-mackenzie/>.

73 The University of Nalanda in Bihar, India, was one of the earliest residential universities in the world from the fifth century CE until 1197 when it was destroyed. At its height it reputedly had as many as 2000 teachers, 10,000 students (from Tibet, Greece, Persia and China) and an extensive library.

${ }^{74}$ Mackenzie, p. 65.

75 Ibid., p. 15.

76 Ibid., p. 26

77 Ibid., p. 56.

${ }^{78}$ Adrian Snodgrass and David Coyne, Interpretation in Architecture: Design as Way of Thinking Abingdon, Routledge, Oxford and New York, 2006, p. 185.

79 Ibid, p. 187.

${ }^{80} \mathrm{Chi} \mathrm{Vu}$, pp. 52; 54; 57. 
81 Ibid, pp 104; 105

82 Jose, 'pp. $5,7$.

83 Smith, p. 325.

\section{-BIBLIOGRAPHY}

Agamben, G., What is an Apparatus? And Other Essays, trans. David Kishik and Stefan Pedatella, Stanford University Press, Stanford, 2009.

Atkinson, S., 'Review: Borobodur by Jennifer Mackenzie', Mascara Literary Review, 2007, $<$ http://mascarareview.com/stephen-atkinson-reviews-borobudur-by-jennifer-mackenzie/>.

Castro, B., 'Writing Asia', Australian Humanities Review, April 1996, <http://www.australianhumanitiesreview.org/archive/Issue-April-1996/Castro.html>.

Chi Vu, Anguli Ma: A Gothic Tale, Giramondo, Sydney, 2012.

De Kretser, Michelle, Questions of Travel, Allen \& Unwin, Sydney, 2012.

Gadamer, H-G., Truth and Method, 2nd rev. edn. trans. and revised Joel Weinsheimer and Donald G. Marshall, Continuum Publishing, New York, 2000, p. Quoted in Snodgrass and Coyne.

Gerster, R., 'Representations of Asia', in Peter Pierce (ed.), The Cambridge History of Australian Literature, Cambridge University Press, Cambridge, 2009. doi: http://dx.doi.org/10.1017/CHOL9780521881654.016

Jose, N., 'Everyday and Exotic: Australian Asian Writing', The Long View-The Wheeler Centre: Books, Writing, Ideas, 2012, <http://wheelercentre.com/projects/the-long-view/book/everyday-andexotic-australian-asian-writing/>.

Mackenzie, J., 'Writing Borobodur', Sotto Magazine, October 2012, <http://www.australianpoetry.org/2012/10/18/writing-borobudur/>.

Mackenzie, J., borobodur, Transit Lounge Publishing, Melbourne, 2009.

Ravenscroft, A., The Postcolonial Eye: White Australian Desire and the Visual Field of Race, Ashgate Publishing, Surrey, 2012.

Said, E.W., Orientalism, Routledge and Kegan Paul, London, 2003.

Smith, T., Contemporary Art: World Currents, Laurence King Publishing, London, 2011.

Snodgrass, A. and D. Coyne, Interpretation in Architecture: Design as Way of Thinking Abingdon, Routledge, Oxford and New York, 2006.

Snodgrass, A., 'Asian Studies and the Fusion of Horizons', Asian Studies Review, vol. 15, no. 3, 1992. doi: http://dx.doi.org/10.1080/10357823.1992.9755385

Snodgrass, A., 'Random Thoughts on the Way: The Architecture of Excursion and Return', Architectural Theory Review, vol. 6, no. 1, 2001. 
Wright, K., 'Gadamer: The Speculative Structure of Language', in Brice R. Wachterhauser (ed.), Hermeneutics and Modern Philosophy, State University of New York Press, Albany, 1986. 